Отримано: 24.05.2019 p.

Прорецензовано: 14.06.2019 p.

Прийнято до друку: 24.06.2019 p.

email: ivan.shyshkin@oa.edu.ua

DOI: $10.25264 / 2409-6806-2019-28-150-155$
Шишкін І. Концепції вирішення української проблеми впольській політичній думці (1939-1945 рр.). Наукові записки Національного університету «Острозька академія». Серія «Історичні науки». Острог, 2019. Вип. 28. C. $150-155$.

\title{
Іван Шишкін
}

\section{КОНЦЕПЦІЇ ВИРІШЕННЯ УКРАЇНСЬКОЇ ПРОБЛЕМИ В ПОЛЬСЬКІЙ ПОЛІТИЧНІЙ ДУМЦІ (1939-1945 РР.).}

У статті досліджено конщепщії вирішення украӥнської проблеми в польській політичній думиі 1939-1945 рр. Основну увагу приділено аналізу різного роду аналітичних опрачювань, доповідних записок, теоретичних розробок, інформачійних довідок, здійснених різними структурними елементами польського еміграчійного уряду, які активно прачювали над виробленням позиції щодо українського питання. Охарактеризовано офіиійні декларачії, прийняті польським урядом в еміграиіі стосовно національних меншин загалом і українського питання зокрема. Висвітлені програмні документи основних політичних партій, що входили до польського «Лондонського табору». Це дало можливість з'ясувати позиції різних політичних сил та дати оцінку їхнім пропозиціям.

Ключові слова: украйнська проблема, польська політична думка, еміграційний уряд, «Лондонський табір», польські політичні партії, Делегатура уряду, Армія Крайова.

\section{Ivan Shyshkin}

\section{CONCEPTS OF THE RESOLUTION OF THE UKRAINIAN PROBLEM IN THE POLISH POLITICAL THOUGHT (1939-1945)}

The article is devoted to the study of Polish-Ukrainian relations during the Second World War. In particular, the concepts of solving the Ukrainian question in the Polish political thought of the period 1939-1945 are investigated. It should be noted that the primary attention is paid to the analysis of various kinds of analytical studies, memos, theoretical developments, informational reports carried out by various structural elements of the Polish emigration government, which actively worked on the development of the latest position on the Ukrainian question. In addition, the official declarations adopted by the Polish government in emigration concerning both the problem of national minorities in general and the Ukrainian question, in particular, are studied. An important role is also played by the study of policy documents of the main political parties that were part of the Polish "London group." This made it possible to highlight the positions of various political forces as well as assess their proposals. The main policy directions of political parties regarding the Ukrainian question are shown. Much attention is dedicated to the study of the program documents of those political parties that cooperated with the Polish government in emigration, and their representatives were included in various structures in its composition, which, in turn, made it possible to directly influence the development of the governmental concepts and its official position. The official statements of such political forces as the National party, the Peasant party, the Democratic party, the LEI (WRN) party (Liberty, Equality, Independence (Wolność, Równość, Niepodlegtość) - the socialist party) are analyzed. Based on the comparison of the crucial program documents, the party press, various kinds of appeals to citizens, the evolution of Polish political thought regarding the Ukrainian question during the Second World War is shown. The official documents developed in the military representation of the government in the country (Home Army), as well as its civilian exposition in the province (Government Delegation), are analyzed.

Keywords: Ukrainian question, Polish political thought, Government in exile "London group," Polish political parties, Government Delegation (Delegatura), Armia Krajowa.

Українсько-польським стосункам у роки Другої світової війни присвячено низку праць. Вагомий внесок у наукове вивчення різних аспектів цієї проблеми здійснили В. В'ятрович, Л. Зашкільняк, О. Каліщук, І. Ільюшин, В. Трофимович, та інші українські науковці. Серед польських авторів варто згадати Р. Тожецького, В. Філяра, В. Бонусяка, Г. Мотику, К. Пжибиша, Е. Дурачинського, А. Фрішке, Ч. Партача тощо. Водночас недостатньо дослідженою залишається позиція польських політичних еліт щодо безпосередньо української проблеми, шляхів ії розв'язання. Потребує більш 
докладного вивчення уся палітра політичних поглядів стосовно України, українців, можливості утворення останніми власної держави, майбутніх заходів польської влади щодо вирішення українського питання тощо. 3 огляду на це, запропонована тема залишається актуальною.

Українсько-польські стосунки в роки Другої світової війни позначені величезною кількістю знакових для обох народів подій як у взаємовідносинах, так і тих, що мали на них визначальний вплив. Міжвоєнний період, нажаль, не приніс порозуміння між поляками і українцями. Польська політична верхівка у своїй переважній більшості не бачила в українцях державної нації і не залишала за ними права на самовизначення. В кращому випадку вона погоджувалася на можливість утворення української держави за Збручем, на теренах УРСР.

Водночас, українська проблема в межах польської держави у міжвоєнне двадцятиліття так і не була вирішена, про що неодноразово заявляли, наприклад, представники українського парламентського клубу від УНДО. Своєрідним тогочасним підсумком двосторонніх відносин стала «Декларація Центрального Комітету УНДО в справі становища українського народу в польській державі» від 7-го травня 1938-го року, в якій уся відповідальність за невдачу політики нормалізації покладалася на офіційну Варшаву [1, арк.2-4].

Після військово-політичної катастрофи восени 1939 р. серед політичної верхівки, очільників політичних партій, громадських діячів, військових та й загалом в усьому польському суспільстві піднімалися питання про причини поразки. Як наслідок, прийшло розуміння, що у майбутній незалежній Польщі потрібні такі реформи і зміни, які б убезпечили їі від повторення цієї загальнонаціональної трагедії. Усі політичні сили погоджувалися з тим, що країні необхідні якісні зміни в усіх сферах життя, починаючи з політичної і закінчуючи соціально-економічною та гуманітарною. Зрозуміло, що різні політичні сили мали відмінні програми і погляди щодо майбутнього держави. На цьому тлі точилися постійні гострі дискусії, адже вони пропонували свої можливі моделі політичного, економічного, культурного розвитку післявоєнної Польщі. Великою мірою останні залежали від політичної платформи тієї чи іншої партії або руху, проте, досить часто, це було продовженням довоєнних напрацювань, які намагалися адаптувати до умов часу.

Одним із наболілих питань, які польська влада так і не змогла розв'язати протягом міжвоєнного періоду була проблема національних меншин, а ії стрижнем - українське питання. 3 огляду на те, що «Лондонський табір» планував збереження Польщі у довоєнних кордонах після закінчення війни, a, можливо, навіть і збільшення території за рахунок отримання «компенсації за втрати» від Німеччини, надзвичайно актуальною ставала й українська справа та можливі шляхи їі вирішення. Про те, що остання була надзвичайно актуальною для поляків, свідчить дуже швидка реакція еміграційного уряду на проблему налагодження контактів з меншинами і українцями зокрема. На Раду міністрів у справах краю 2-го листопада 1939 року було покладено завдання вивчити можливість налагодження співпраці з Литвою, Білорусією та Україною [10, с.56].

Незабаром був створений Комітет у справах краю, на який покладалося завдання розробки базових постулатів для налагодження співпраці з українцями. Вже 28 листопада того ж року він розробив і опублікував декларацію, яку польська сторона вважала інструкцією у справі контактів 3 останніми. Тут йшлося про розуміння урядом українських самостійницьких прагнень, проте, на думку авторів документу, надзвичайно важливим було питання спільної боротьби проти окупантів [8, с.17]. Згідно 3 текстом декларації, Комітет визнавав можливість створення незалежної української держави і навіть готовий був до діалогу з приводу кордонів майбутньої України. У документі підкреслювалося, що Україна і Польща будуть об’єднані у федерацію, в якій користуватимуться рівними правами.

Окреслювалися і можливі шляхи вирішення проблеми майбутніх спільних кордонів. На думку авторів інструкції, дві країни будуть об’єднані в федерацію, а «проходження кордону між Польщею та Україною залежатиме від ступеня взаємопов'язаності федерального устрою» [14, 98]. Документ було передано прем'єру В. Сікорському, проте він не схвалив ідею можливості створення української держави на теренах «східних кресів». На його думку, Польща буде занадто слабкою без українських земель, які фактично відіграватимуть роль буферної зони, бо є «передпіллям стратегічним». Тому було прийнято рішення про те, що декларація відіграватиме лише роль директив у переговорах з українцями [14, с. 97-101].

Офіційну позицію щодо проблеми меншин, а отже й до українського питання, еміграційний уряд висловив досить оперативно. Вже 18 грудня 1939 року в Анжері (Франція) побачила світ декларація, в якій поміж окресленням головних цілей війни була й теза про післявоєнний устрій Польщі. Перед- 
бачалося, що національним меншинам, які взяли участь у боротьбі і залишилися вірними державі, буде забезпечений національний та культурний розвиток, справедливість і правова опіка [11, с.95].

Слід зауважити, що така позиція цілком вписувалася у концепцію побудови післявоєнної Польщі. Після поразки від Німеччини цілком зрозумілим $є$ прагнення виробити такі базисні політичні механізми, які б забезпечили розвиток держав Центрально-Східної Європи і вберегли їх від можливої агресії ззовні. Польський політикум водночас послуговувався тезою про те, що самотужки Річпосполита не зможе організувати і підтримувати безпеку. 3 огляду на це, пропонувалося утворити міждержавне об'єднання, до якого ввійшли б країни регіону. Вже в одній з перших декларацій уряду від грудня 1939 р. йшлося про усвідомлення Польщею своєї місії щодо боротьби з німецьким тиском на схід. Враховуючи негативний попередній досвід боротьби проти німецької експансії, пропонувалося створення солідарного союзу держав регіону між Балтикою, Чорним морем та Адріатикою. Це утворення мало спільно протистояти тиску Німеччини, а також відділити ії від Росії. Саме такий союз, на думку авторів декларації, убезпечив би Польщу від майбутніх небезпек і потрясінь [12, с.1].

У травні 1940 р. українське питання розглядалося на Бєлградській конференції, у якій брали участь представники польського уряду, коменданти баз зв'язку з окупованими територіями і окремі члени польського підпілля з Варшави та Львова. Одним з аспектів, на який звернули увагу учасники конференції, була проблема взаємовідносин з українцями. Зокрема, зазначалося, що «на тлі розчарування політикою більшовиків настав поворот у симпатіях з боку українців в пронімецькому напрямку. Ставлення до поляків було і залишається ворожим, бо українці сподіваються на створення в тій чи іншій формі Самостійної України» [6, с.253].

У середовищі еміграційного уряду ширилися сподівання на те, що цілком вірогідною $є$ війна між союзниками і СРСР. Вважалося, що Радянський Союз з великою вірогідністю розпадеться на окремі державні утворення після поразки від США та Великобританії. На початку 1940 року з'явилося чимало напрацювань, присвячених врегулюванню українського питання внаслідок розпаду СРСР. 3 огляду на це, пропонувалося в необхідний момент підтримувати союзників і усіляко сприяти його розпаду. Зокрема, в одному з таких планів дій читаємо: «Метою організації і підтримки українського збройного руху на Київщині і за Дніпром має бути:

а) диверсія у глибокому тилу більшовицької армії; б) можливий розпад Росії на окремі національно-державні утворення; в) можливе утворення української держави на Наддніпрянщині» [5, арк.1-2].

На думку польських політиків, якщо складуться сприятливі обставини, Польща зацікавлена в проведенні такої акції самостійно, щоб занепад більшовизму ставився їй в заслугу. Згідно з планом, на чолі українських відділів мали стояти поляки, а сама збройна боротьба повинна була виглядати «як боротьба проти ГПУ, комуністичної партії та безбожників, а не проти радянського солдата». Загальний напрямок усього руху мав розпочатися з теренів Румунії - середня Бессарабія, а далі перекинутися на Черкаси і згодом або на Галичину («Східну Малопольщу»), або на Крим, Дон і Кубань [5, арк.1-2]. Слід зазначити, що такого роду плани були далеким від реальної ситуації, але свідчили про величезну популярність ідей «прометеїзму» у середовищі польського політикуму, навіть не зважаючи на існуючі реалії.

Погляди польських еміграційних кіл на українську проблему різнилися між собою. Перша частина (а це були особи, наближені до головнокомандувача) вважала, що в українській справі потрібно дотримуватись обережності, зайняти вичікувальну позицію, а також зважати на думку союзників щодо політичних поступок, які стосувались відносин Польща - СРСР - Україна. Ще одна група, до якої належали представники різних політичних поглядів, але в більшості пілсудчики, стояла на позиції повернення до політики федералізму та необхідності утворення української держави, проте за Збручем. Ендеки та їх прихильники були категорично проти утворення будь-якої української держави, вважаючи визначальними російський і польський народи і стверджуючи, що незалежна Україна не гарантуватиме безпеки польській державі і постійно нагадуватиме про Волинь і Галичину [13, c.324].

Варто зауважити, що ні польський уряд на еміграції, ні його представництва (військове та цивільне) в країні не могли зайняти чіткої офіційної позиції, бо змушені були узгоджувати свої вимоги з Великобританією і США, які, своєю чергою, не бажали втрачати такого союзника як СРСР. Саме тому офіційна декларація польського уряду щодо українського питання побачила світ лише на п’ятому (1943 р.) році війни. 3 огляду на це, можна виокремити два джерела інформації для вивчення проблеми у період 1939-1943 рр.: офіційні декларації уряду по національним меншинам загалом, а 
також неофіційна позиція представників уряду, його експозитур на місцях і представників різних політичних сил у складі польського «Лондонського табору».

Одна з офіційних декларацій, де значну увагу присвячено проблемі меншин, побачила світ майже відразу після початку німецько-радянської війни - наприкінці липня 1941 року. Вона проголошувала Польщу демократичною державою, що забезпечить рівність усіх громадян незважаючи на расу, національність чи віросповідання. Документ гарантував усі права слов'янським меншинам, литовцям та євреям, хоча не передбачав їх стосовно німців [11, с.95].

Під час відкриття сесії новоствореної Національної ради (24 лютого 1942 р.) В. Сікорський озвучив програмні тези уряду щодо політики меншин. Вони фактично повторювали головні постулати липневої декларації. Йшлося про те, що усім представникам національних меншин - громадянам Польщі, які були їй вірні, будуть забезпечені загальна рівність і громадянські права. Їм загалом гарантувалися «при різних обов’язках рівні права» і надання можливостей для політичного, культурного і суспільного розвитку [7, с.1].

Із середини 1942 р. еміграційний уряд почав приділяти більше уваги розробці концепції взаємовідносин з українцями. Зокрема, влітку 1942 р. у Лондоні відбулося кілька нарад, присвячених українському питанню, які було скликано керівником Міністерства закордонних справ Е. Рачинським. У ході обговорення можливих варіантів його розв'язання присутні на засіданні члени уряду прийшли до висновку, що серед українських діячів, з якими є можливість налагодити контакти, немає жодної впливової у середовищі українського національного руху особи. Крім того українська проблема навряд чи буде підніматися на міжнародному рівні, бо у цьому не зацікавлений перш за все Радянський Союз і сумнівним є те, що вона буде підтримана Німеччиною. Загалом усі присутні погодилися 3 тим, що потрібно розробити кілька альтернативних варіантів розв'язання українського питання, які мали залежати від ситуації на міжнародній арені [9, с.253-256].

У контексті зростання уваги до української проблеми керівних польських кіл слід розглядати й звернення по радіо президента В. Рачкевича «До білорусів і українців». Виступ відбувся наприкінці літа 1942 р. і його відразу ж було опубліковано на сторінках періодичного видання «Східні Землі Речіпосполитої» («Ziemie Wschodnie Rzeczypospolitej») за вересень 1942 р. У ньому він розкритикував політику попередніх урядів стосовно українців, назвавши іiі «політикою ігнорування українського питання». Президент також підкреслив, що поляки мусять зрозуміти прагнення українців до незалежності, проте й українці мають «усвідомити, що їхнє майбутнє нерозривно пов’ язане 3 майбутнім Речіпосполитої, а Україна може існувати лише за умов опори на Польщу». В. Рачкевич наголосив, що українська держава має право на існування лише на Наддніпрянщині із столицею в Києві, бо «східні землі» Речіпосполитої «не є Україною», тому ії побудова на теренах «східних кресів, є нонсенсом», а український національно-визвольний рух, який він назвав сепаратизмом, «прикривається гаслами боротьби за визволення України» [15, с.4-5]. У вищенаведених висловлюваннях проглядається чітка позиція неприйняття можливості входження теренів Західної України до складу майбутньої незалежної української держави.

Нарешті після довгих дискусій і обговорень 31-го березня 1943 р. польський уряд ухвалив «Тези в справі української політики». Згідно з документом, уряд надавав українцям гарантії усіх прав і фактичного зрівняння в правах з поляками в політичній, культурній, мовній, господарській і суспільній площинах. Зокрема, це мало відбутися шляхом запровадження в Речіпосполитій широко розбудованої системи органів територіального самоврядування до воєводського рівня включно, 3 наданням законодавчих повноважень відповідним установам у вирішенні місцевих справ, що не підлягатимуть центральному законодавству. Крім того, гарантувались: опіка і підтримка в питаннях культури, освіти, свобода віросповідання, проведення земельної реформи, співпраця в сфері створення статуту самоврядування тощо. Зі свого боку, українці, на думку поляків, мають: опублікувати декларацію, що засуджувала б радянські претензії на терени Західної України, змінити спрямованість тематики української преси в інтересах польсько-українського поєднання, створити спільний фронт боротьби проти німецьких окупантів, організувати спільну протидію «новим імперіалістичним домаганням Радянської Росії», а також запобігати усіляким взаємним ворожим виступам на завершальному етапі війни [3, арк. 1].

Слід зазначити, що, по-перше, документ було написано в дусі політики «федералізму» і «прометеїзму», по-друге, він абсолютно не вирішував наболілого для українців питання про визнання Польщею їхніх прав на входження теренів Західної України до складу незалежної Української дер- 
жави, по-третє, прийняття саме такої декларації завело в глухий кут переговори між українським та польським підпіллям і було неоднозначно сприйняте керівними колами останнього. Радикально налаштовані представники польського політикуму заявляли про зраду національних інтересів, а ті, хто виступав за співпрацю з українцями, навпаки, говорили, що документ абсолютно не відповідає реаліям і не може допомогти у налагодженні стосунків. Після прийняття березневої декларації представники українського національного руху зрозуміли, що польська сторона не збирається йти на поступки у питанні про приналежність західноукраїнських територій. Саме це стало однією з причин подальшого загострення їхніх взаємин.

Обговорення української проблеми відбувалось і на засіданнях Польського комітету порозуміння (ПКП), до складу якого входили представники чотирьох найбільших і найвпливовіших партій - Стронніцтва народового, Стронніцтва праці, Соціалістичної партії - ВРН, Стронніцтва людового. Частина членів ПКП виступала за їі радикальне розв'язання. Зокрема, ідею примусового виселення українців обстоювали представники Стронніцтва народового. За депортацію проголосувало також Стронніцтво праці. 3 ними не погоджувалися діячі ВРН і Стронніцтва людового, які в цілому не заперечували проти переселення українців з територій «східних кресів», проте зазначали, що воно має відбуватися виключно на добровільних засадах [2, с.122-123]. Варто зауважити, що серед польських політичних партій і угруповань та й в середовищі уряду і його представництв не існувало одностайної позиції щодо шляхів вирішення української проблеми. 3 точки зору ставлення до України і українців політичні партії та різного роду організації умовно поділялися на три групи, в середині яких також існували відмінності. Перша представляла партії та організації націоналістичного спрямування, які взагалі нехтували українською проблемою, виступаючи за екстермінаційну політику щодо українців, аж до цілковитого їх виселення з теренів Польщі. Сюди відносилися Стронніцтво народове, Шанець та Конфедерація нації. Друга стояла на позиції неподільності територій Речіпосполитої та збереження кордонів, що існували до вересня 1939 р., розглядаючи необхідність вирішення української проблеми в межах польської державності і виступала за надання українській меншині повного громадянського рівноправ'я, послуговуючись принципом «рівні обов'язки - рівні права». Ї̈̈ представники вважали можливим утворення української держави, але лише за Збручем і 3 центром у Києві, а не у Львові. Серед угруповань, що стояли на таких позиціях, були Стронніцтво людове, Стронніцтво праці, ВРН. Нарешті, третя група - так званий напрямок «національної автономії», представлений Демократичною партією та партією Польські Соціалісти (ПС), які підтримували концепцію надання українцям автономії на теренах Західної України [4, арк.1-4]. Слід зауважити, що жодна з польських політичних партій та угруповань не розглядала і не підтримувала можливості входження «східних кресів» до складу незалежної української держави, вважаючи їх невід'ємною частиною Польщі.

Отже, протягом 1939-1945 років польська політична думка пройшла складний еволюційний шлях у ставленні до української проблеми. Зокрема було розроблено низку планів, інструкцій, оголошено різного роду декларації. Проте, протягом усього воєнного часу, так і не вдалося виробити чіткої позиції, що би дозволила розв'язати наболілу проблему. Головними причинами невдач у вирішенні українського питання стали: небажання поступатися в питаннях кордонів, несприятлива для польської рації стану міжнародна ситуація, недовіра та негативне ставлення до поляків українців, а також неприйнятність двосторонніх вимог i, водночас, несприйняття більшістю польського політикуму ідеї входження західноукраїнських земель до складу української незалежної держави.

\section{Список використаних джерел та літератури:}

1. Archiwum Akt Nowych AAN. Armia Krajowa (AK). Sygn. 202/III-197. Ark. 2-4.

2. AAN. Armia Krajowa. Sygn. 203/XV-45.

3. AAN. Delegatura Rządu RP na Kraj. Sygn. 202/II-50. Ark. 1.

4. AAN. Delegatura Rządu RP na Kraj. Sygn. 202/III-10. Ark. 1-4.

5. Archiwum Zakład Historii Ruchu Ludowego (AZHRL) w Warszawie. Materiały S. Kota. Sygn. 407.

6. Armia Krajowa w dokumentach 1939-1945. Wrocław; Warszawa; Kraków, 1990. T.1. 584 s.

7. Deklaracja programowa Rządu RP. Rzeczpospolita Polska. №4(23) z 10 marca, 1942.

8. Partacz Cz. Kwestia ukraińska w polityce polskiego rządu na uchodźstwie i jego ekspozytur w kraju (19391945). Koszalin, 2001. $405 \mathrm{~s}$.

9. Partacz Cz., Łada K. Polska wobiec ukraińskich dążeń niepodległościowych w czasie II wojny światowej. Toruń, 2004. $412 \mathrm{~s}$. 
10. Protokoły z posiedzeń Rady Ministrów Rzeczypospolitej Polskiej. Kraków, 1994.T. I (październik 1939czerwiec 1940).349 s.

11. Przybysz K. Polska myśl polityczna (1939-1945): zarys problematyki. Warszawa, 2000. $266 \mathrm{~s}$.

12. Rodacy! Pobudka. Nr. Specialny. № 5(14) z lutego 1940.

13. Torzecki R. Kontakty Polsko-Ukraińskie na tle problemu ukraińskiego w polityce polskiego Rządu Emigracyjnego i Podziemia (1939-1944). Dzieje najnowsze. Warszawa, 1981. Rocznik XIII. S. 319-346.

14. Torżecki R. Polacy i ukraińcy. Warszawa, 1993. 349 s.

15. Źiemie Wschodnie Rzeczypospolitej. Maj, 1942. №2. 